\title{
KAZAKHSTAN'S MULTIETHNICITY: FACTOR OF INTER-ETHNIC TENSION AND DEVELOPMENT OF CROSS-BORDER TOURISM
}

\author{
Ruslan A. KARATABANOV* \\ L.N. Gumilyov Eurasian National University, Faculty of Natural Sciences, Department \\ of Physical and Economic Geography, Kazhymukan 13, building 3, Nur-Sultan 010008, \\ Republic of Kazakhstan, e-mail: ruslan.karatabanov@gmail.com
}

Kulchikhan M. JANALEYEVA

L.N. Gumilyov Eurasian National University, Faculty of Natural Sciences, Department of Physical and Economic Geography, Kazhymukan 13, building 3, Nur-Sultan 010008, Republic of Kazakhstan, e-mail: dzhanaleeva44@mail.ru

\begin{abstract}
Sergey V. PASHKOV
M. Kozybayev North-Kazakhstan State University, Faculty of Mathematics and Natural Sciences, Pushkin str. 86, Petropavlovsk 1500oo, Republic of Kazakhstan, e-mail: sergp2001@mail.ru
\end{abstract}

\begin{abstract}
Citation: Karatabanov, R.A., Janaleyeva, K.M \& Pashkov, S.V. (2020). KAZAKHSTAN'S MULTIETHNICITY: FACTOR OF INTER-ETHNIC TENSION AND DEVELOPMENT OF CROSS-BORDER TOURISM. GeoJournal of Tourism and Geosites, 29(2), 732-745. https://doi.org/10.30892/gtg.29227-502
\end{abstract}

\begin{abstract}
The Republic of Kazakhstan seeks to strengthen the protection of the country's geopolitical interests. The main focus is to maintain the control over its territory. The Republic of Kazakhstan is a multiethnic state. Ethnic diversity poses the risk of ethnic conflicts and adverse geopolitical consequences. Therefore, defining areas with high potential for interethnic conflict is a priority for geopolitical research. This article discusses issues related to the phenomenon of "ethnic tension". The authors studied the ethnic composition of society, the settlement of ethnic groups and the culture of interethnic communication. Based on the census data and using statistical methods for each ethnic group and region, ethnic tension coefficients for entire country were calculated. Regions with a certain risk of ethnic conflicts were identified according to their values. Maps of Kazakhstan regions with high values of ethnic tension coefficients were compiled using the ArcGIS software. At the same time, ethnic diversity is a valuable resource for developing cross-border tourism.
\end{abstract}

Key words: ethnic composition, ethnicity, ethnic groups, ethnic tension, ethnic conflict, geopolitics, cross-border tourism, sentimental tourism

\footnotetext{
* Corresponding author
} 


\section{INTRODUCTION}

As of early 2019, the population of the Republic of Kazakhstan was 18,395,567. Kazakhstan is a multiethnic country. It is home to Kazakhs, Russians, Uzbeks, Ukrainians, Uighurs, Tatars, Germans, Turks, Koreans, Azerbaijanis, Dungans, Belarusians, Tajiks, Kurds, Chechens, Poles, Bashkirs and other ethnicities. The beginning of the conflict in Ukraine in 2014 sparked another research interest in ethnic situation in Kazakhstan. In his book "The Clash of Civilizations and the remaking of World Order”, S. Huntington wrote that: “... The more fundamental divisions of humanity in terms of ethnicity, religions, and civilizations remain and spawn new conflicts" (Huntington, 1996, p. 66). The Republic of Kazakhstan, as a multiethnic state situated at the crossroads of world civilizations, is one of the regions of the planet with potential risks of ethnic conflicts. In this regard, the interaction between ethnic groups in one sociocultural space and searching for mechanism of peaceful communication is a priority issue in contemporary geopolitics (Zupančič et al., 2018). In this situation, the importance of forecasting ethnic conflicts is significantly higher and, consequently, the science is more accountable to society for such forecasts. If growing tensions between ethnic groups in a specific area of the country are foreseen well in advance, it is possible to prevent the conflict and its major consequences. Therefore, research in this field is now more relevant than ever. "Ethnic tension (ET) is characterized as specific mental state of ethnic community, which is formed in the process of reflection by collective ethnic consciousness of a combination of unfavorable external conditions that infringe on the interests of ethnic group, destabilize its position and impede its development” (Asaul et al., 2010).

The purpose of the study is to identify areas of Kazakhstan with high risk of ethnic conflicts, which should be considered in the course of their prevention and resolution. To achieve this goal, the authors successively addressed the following tasks: 1 ) calculate interethnic tension coefficient based on the analysis of ethnic composition of Kazakhstan population; 2) reflect interethnic tension coefficient data on the map; 3) identify areas with high risk of ethnic conflict. The findings of this study can be used by Kazakhstan Government in implementing demographic and migration policy in order to bring the interethnic tension coefficient in certain regions closer to safe values. The security agencies, local executive bodies and the Assembly of the People of Kazakhstan can also use the findings to enhance the effectiveness of projected and currently implemented activities.

\section{RESEARCH MATERIALS AND METHODS}

The risks of ethnic conflict in Kazakhstan were analyzed based on the ethnic composition of the country's population according to the methodology for identifying potential regions of ethno-political disintegration in Table 1 (Asaul et al., 2010; 65-72).

Table 1. Determining interethnic tension (IET) with regard to the influence of ethnic group in the total population of the country (TP) (Data source: Asaul et al., 2010; 65)

(the percentage of a certain ethnic group in the total population is indicated in\%)

\begin{tabular}{|c|c|c|c|c|c|}
\hline \multicolumn{7}{|c|}{ Scale of interethnic tension levels } \\
\hline 1 & 2 & 3 & 4 & 5 & 6 \\
\hline Insignificant IET & Palpable IET & Essential IET & Significant IET & Very strong IET & Extreme IET \\
\hline \%\%-0,5\% & $0,5 \%-5 \%$ & $5 \%-25 \%$ & $25 \%-50 \%$ & $50 \%-90 \%$ & $90 \%-100 \%$ \\
\hline
\end{tabular}

This scale is determined by the specific weight of any ethnicity in the total population of the country. At the first level, the IET is virtually absent and is primarily 
manifested in private. At the second level, the ethnic group is in the position of absolute minority and can count on self-governance on non-essential issues (for example, the development of ethnic culture). At the third and fourth levels of IET, ethnic groups within some regions are characterized by a certain predominance and claim a wide range of selfgovernance. At the fifth and sixth levels of IET, ethnic groups have the most favorable conditions for an absolute and dominant position in all areas of public life within their regions. Regions where, in addition to Kazakhs, there are ethnic groups with IET values of $>5$ have a risk of being involved in ethnic conflicts. With such high values of IET, the likelihood of separatist sentiments and threats to territorial integrity and unitary structure of the country is significantly greater. The Republic of Kazakhstan is a unitary state with a presidential form of government. The sovereignty of the Republic shall cover the whole of its territory. The state shall ensure the integrity, inviolability, and inalienability of its territory. Regions predominantly populated by the Kazakh ethnic group do not have high risks of ethnic conflicts. Spatial analysis and synthesis of data were performed using the ArcGIS 10.4.1 geographic information system.

\section{RESULTS AND DISCUSSION}

Specific IET levels were calculated in several stages. The calculations were made for entire country and by regions. At the stage I, based on the data obtained from the Committee on Statistics of the Ministry of National Economy of the Republic of Kazakhstan, the degree of influence of country's largest ethnic groups on the level of interethnic tension was determined in accordance with the data given in Table 2.

Table 2. The degree of influence of ethnic groups on the level of interethnic tension. The proportion of particular ethnicities in the total population of Kazakhstan at the beginning of 2019, \% (Data source:

Statistics Committee of the Ministry of National Economy of the Republic of Kazakhstan for 2019 [1])

\begin{tabular}{|l|c|c|c|}
\hline Ethnic group & Number of people & Proportion \% & Degree of influence on IET \\
\hline Kazakhs & 12505251 & 67,98 & 5 \\
\hline Russians & 3553232 & 19,32 & 3 \\
\hline Uzbeks & 590993 & 3,21 & 2 \\
\hline Ukrainians & 270916 & 1,47 & 2 \\
\hline Uighurs & 270916 & 1,47 & 2 \\
\hline Tatars & 201492 & 1,10 & 2 \\
\hline Germans & 178029 & 0,97 & 2 \\
\hline Turks & 112107 & 0,61 & 2 \\
\hline Koreans & 108396 & 0,59 & 2 \\
\hline Azerbaijanis & 110341 & 0,60 & 2 \\
\hline Dungans & 72361 & 0,39 & 1 \\
\hline Belarusians & 54690 & 0,30 & 1 \\
\hline Tajiks & 48749 & 0,27 & 1 \\
\hline Kurds & 46348 & 0,25 & 1 \\
\hline Chechens & 33318 & 0,18 & 1 \\
\hline Poles & 30456 & 0,17 & 1 \\
\hline Bashkirs & 16732 & 0,09 & 2 \\
\hline Other & 192060 & 1,04 & \\
\hline
\end{tabular}

The calculations were made by the author according to the data of Kazakhstan population as of early 2019 obtained from the Committee on Statistics of the Ministry of National Economy of the Republic of Kazakhstan.

At the stage II, the data obtained at stage I (Table 1) were used to determine the interethnic tension coefficient calculated according to formula 1 (Asaul et al., 2010; 65-72): 


$$
\mathrm{C}_{I E T}=\frac{D E_{T P}-D_{I E T}^{\prime}}{D_{I E T}^{\prime \prime}-D_{I E T}^{\prime}}+N_{I E T}
$$

where $\mathbf{C}_{\text {IET }}$ is the interethnic tension coefficient, $\mathbf{D E}_{\mathbf{T P}}$ is the proportion (\%) of ethnic group in the total population of the country, $\mathbf{D}_{\text {IET }}$ is the lower value of the proportion (\%) of ethnic group on ET level scale, $\mathbf{D}_{\text {ET }}$ is the upper value of the proportion (\%) of ethnic group on ET level scale, $\mathbf{N}_{\mathbf{E T}}$ - level number on ET level scale.

The calculation procedure can be demonstrated by the example of the Kazakh ethnic group the formula 1 (calculation made by the authors):

$$
C_{I E T}=\frac{67,98-50}{90-50}+5=5,45
$$

$\mathrm{C}_{\mathrm{IET}}$ of Kazakhstan's ethnic groups are given in Figure 1.

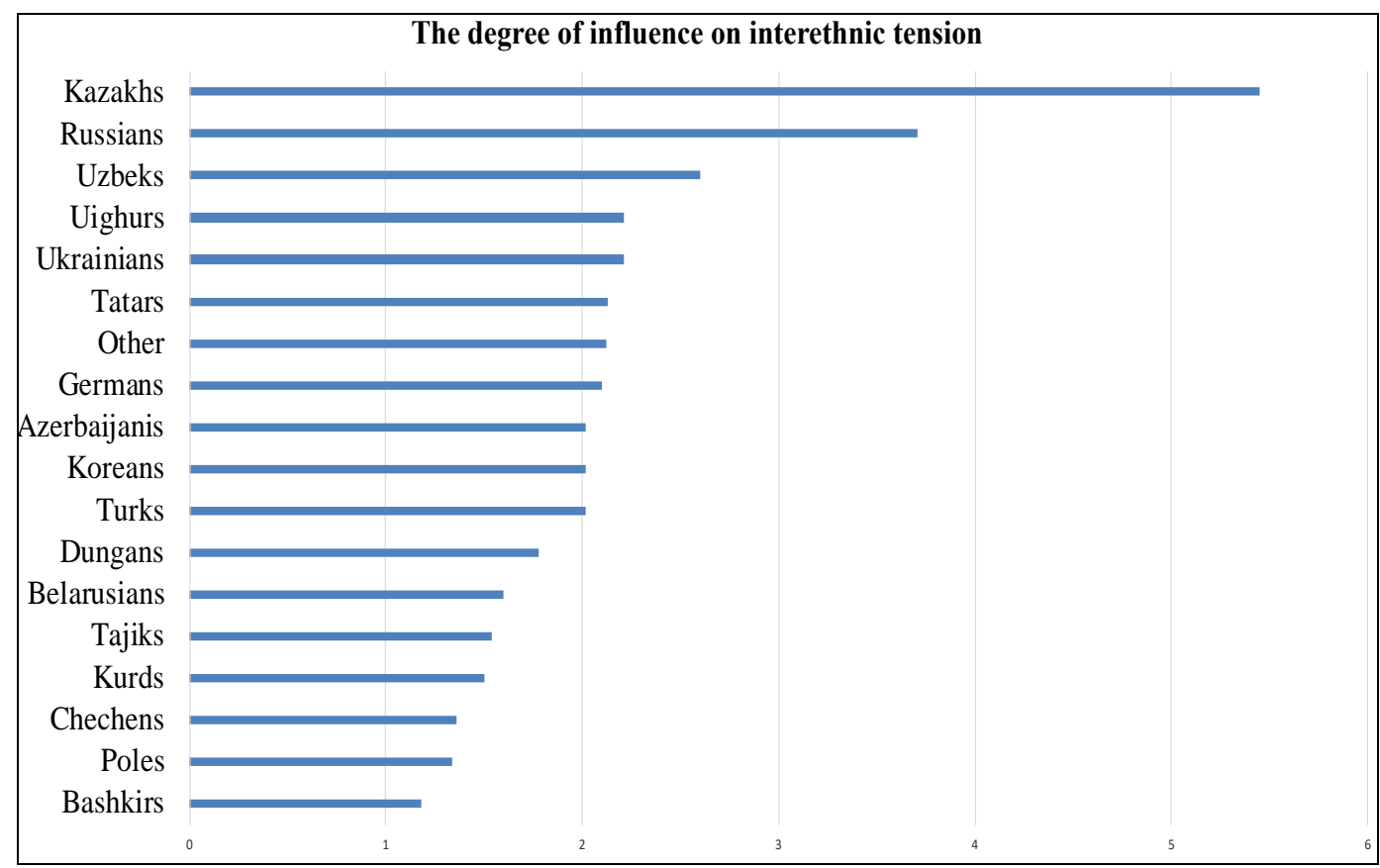

Figure 1. $\mathrm{C}_{\mathrm{IET}}$ of ethnic groups in Kazakhstan (Source: Statistics Committee of the Ministry of National Economy of the Republic of Kazakhstan for 2019 [1])

It was established that at the country level there are only 2 ethnic groups with $\mathrm{C}_{\mathrm{IET}}$ 3 and higher - Kazakhs and Russians. The proportion of other ethnic groups is roughly identical, and the influence of a particular ethnic group in the multi-ethnic structure of the population is insignificant. At the regional level, due to the densely populated nature of settlements, the picture will be more convincing. Therefore, at the stage III, interethnic tension coefficients regionally exerted by particular ethnic groups were calculated according to formula 1 (based on the proportion in the total population of the region as of early 2019). In terms of administrative structure, the Republic of Kazakhstan is divided into 14 regions and 3 cities of national significance. The results are given in Figure 2. 


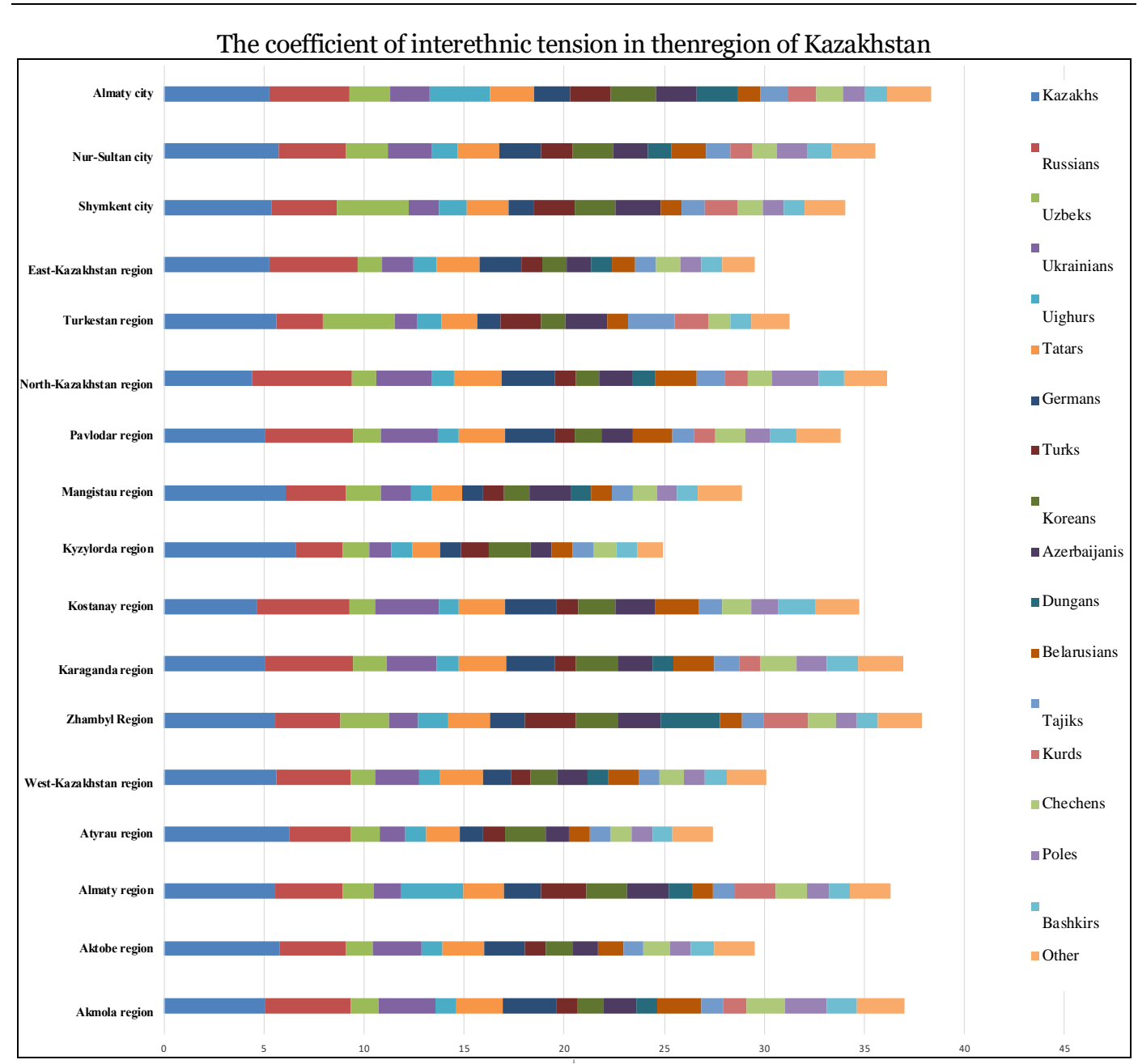

Figure 2. СіЕт of ethnic groups in the regions of Kazakhstan (Source: Statistics Committee of the Ministry of National Economy of the Republic of Kazakhstan for 2019 [1])

The country's population is unevenly distributed. According to Figure 2, the ethnic composition of population in Kazakhstan regions is different and some ethnic groups have interethnic tension coefficient of greater than 3. So, Kazakhs have $\mathrm{K}_{\mathrm{ET}}$ of more than 3 in all 17 regions, Russians in 15 regions, Uzbeks in 2 regions, Ukrainians in 1 region, Uyghurs in 2 regions, Dungans in 1 region. These results suggest that in certain parts of each region there are areas densely populated by specific ethnic groups and their $K_{\mathrm{ET}}$ value will be higher than the average for the country or region. At the stage IV, data on population in administrative areas (districts) of each region were analyzed. The composition of 14 regions includes 163 rural districts, 37 cities of regional significance ( 1 such city - 1 district). In the cities of national significance, there are distinct urban areas: 4 in Nur-Sultan, 8 in Almaty, 4 in Shymkent. In total, the composition of 216 administrative areas was analyzed.

At this stage, it was established that the proportion of particular ethnic groups in the total population of administrative areas, regions and cities of national significance exceeds $5 \%$ and has $\mathrm{K}_{\mathrm{ET}}$ of $>3$. At the stage $\mathrm{V}$, the authors compiled a map for ethnic groups like Kazakhs, Russians, Uzbeks, Ukrainians, Uyghurs, Germans, Turks, Koreans, Azerbaijanis, 
Dungans, Tajiks, Chechens, Poles and Tatars, in order to get a spatial drawing of $\mathrm{K}_{\mathrm{ET}}$ distribution. Kazakhs have $\mathrm{K}_{\mathrm{ET}}>3$ in all 216 administrative areas (Figure 3), Russians in 149 (Figure 4), Ukrainians in 40 (Figure 5), Germans in 25 (Figure 6), Uzbeks in 14, Uighurs in 8 (in 4 districts of Almaty city, Uighur, Talgar, Enbekshikazak and Panfilov districts of Almaty region), Turks in 4 (in Baizak, Zhambyl, Merken and Shu districts of Zhambyl region; in 2 districts of Almaty region - Enbekshikazak and Karasai - the influence Turkish diaspora is close to 5), Koreans in 1 (Karatal district of Almaty region), Azerbaijanis in 1 (Tulkibas district of Turkestan region), Dungans in 2 (Zhambyl and Kordai districts of Zhambyl region), Tajiks in 3 (Zhetysai, Maktaaral and Saryagash districts of Turkestan region), Chechens in 1 (Sandyktau district of Akmola region), Poles in 2 (Astrakhan district of Akmola region and Tayinshi district of North Kazakhstan region), Tatars in 1 (Mamlyut district of North Kazakhstan region) (Figure 7).

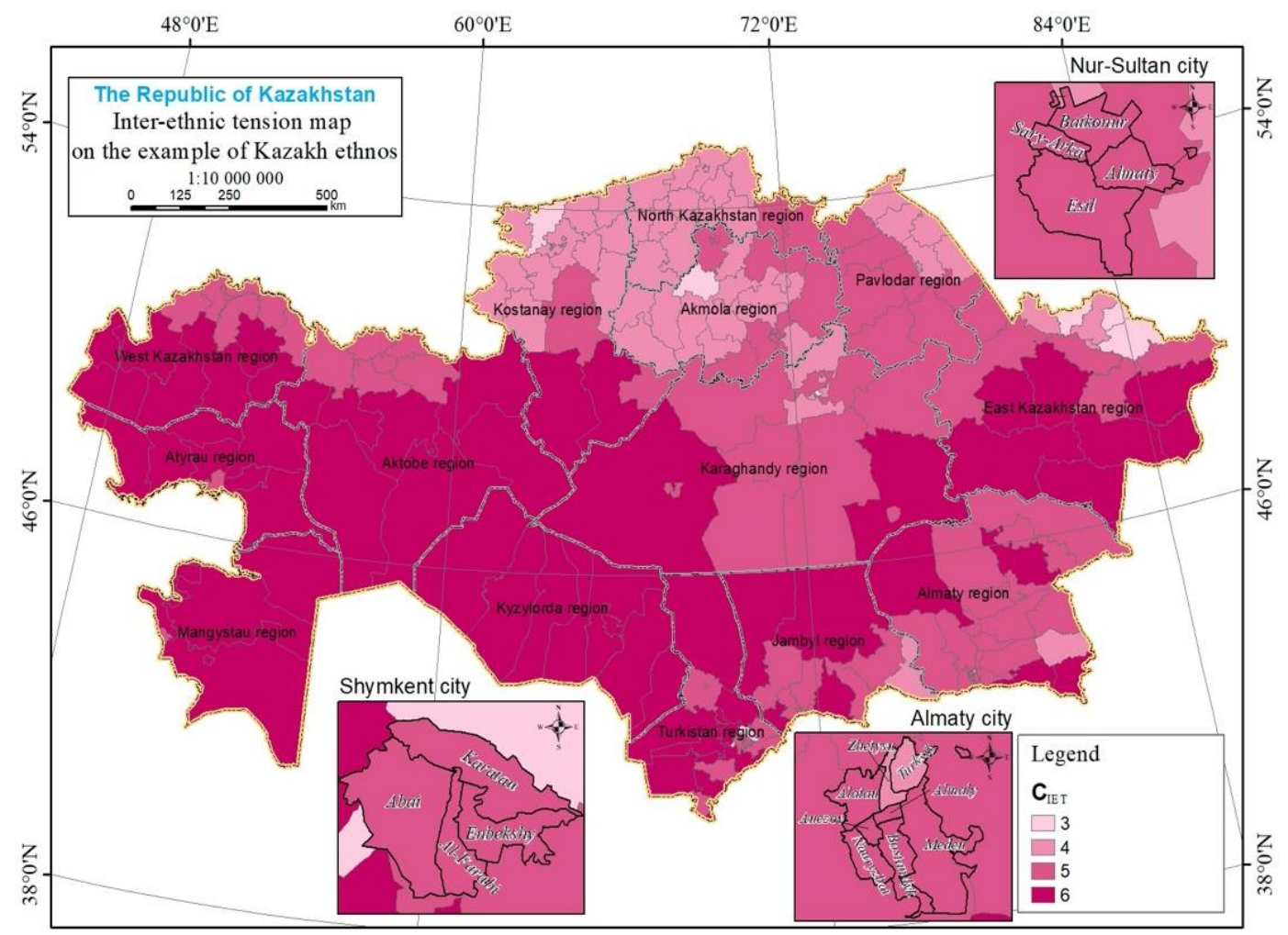

Figure 3. Map of interethnic tension of the Kazakh ethnic group (Source: Statistics Committee of the Ministry of National Economy of the Republic of Kazakhstan for 2019 [1])

Areas with high interethnic tension exerted by particular ethnic groups can form entire continuous zones. For instance, one zone of interethnic tension exerted by Kazakh ethnic group extends along the southern Kazakhstan. The second zone in sub-latitudinal direction runs along the northern Kazakhstan from West Kazakhstan to East Kazakhstan region, covering the Karaganda region (Figure 3-6). This zone is formed by ethnic groups like Russians, Ukrainians, Germans, etc. Some ethnic groups form enclave zones of interethnic tension (Tajiks, Dungans, Azerbaijanis, Koreans, Uzbeks, Uighurs, Turks). This phenomenon is mainly seen in southern Kazakhstan (Figure 7). Areas of Tatar, Polish and Chechen ethnic groups are part of the northern zone of interethnic tension. 


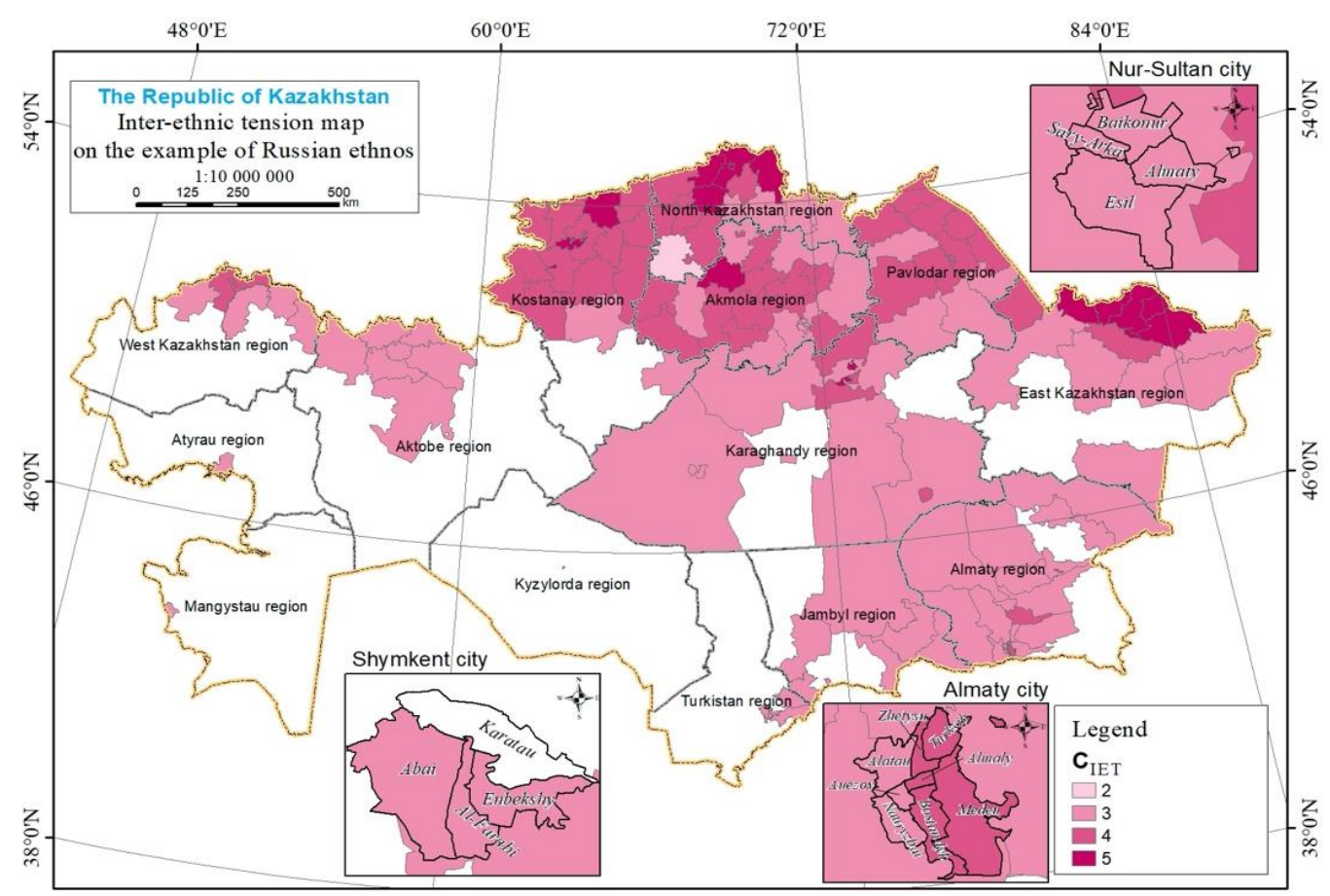

Figure 4. Map of interethnic tension of the Russian ethnos (Source: Statistics Committee of the Ministry of National Economy of the Republic of Kazakhstan for 2019 [1])

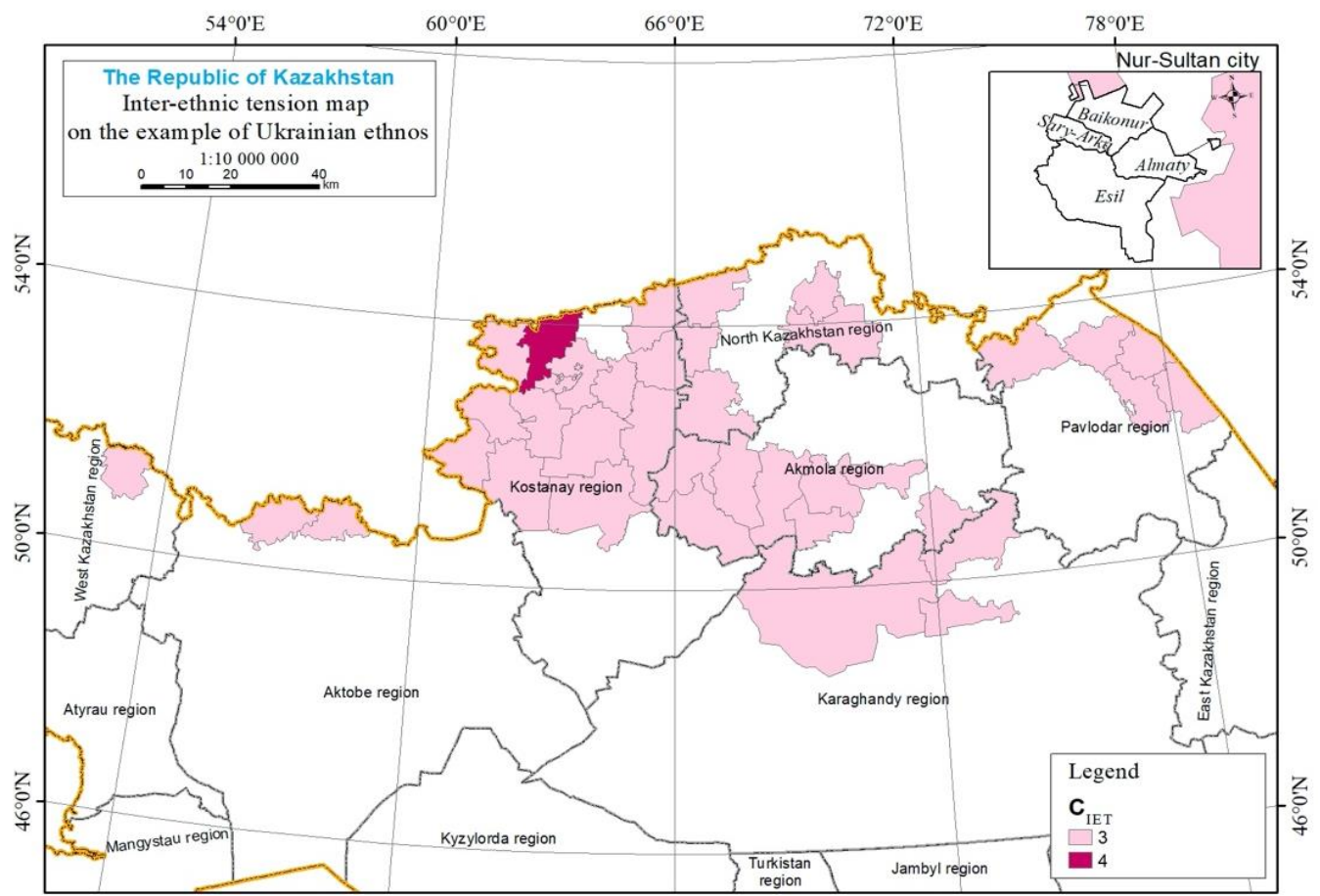

Figure 5. Map of interethnic tension of the Ukrainian ethnic group (Source: Statistics Committee of the Ministry of National Economy of the Republic of Kazakhstan for 2019 [1]) 


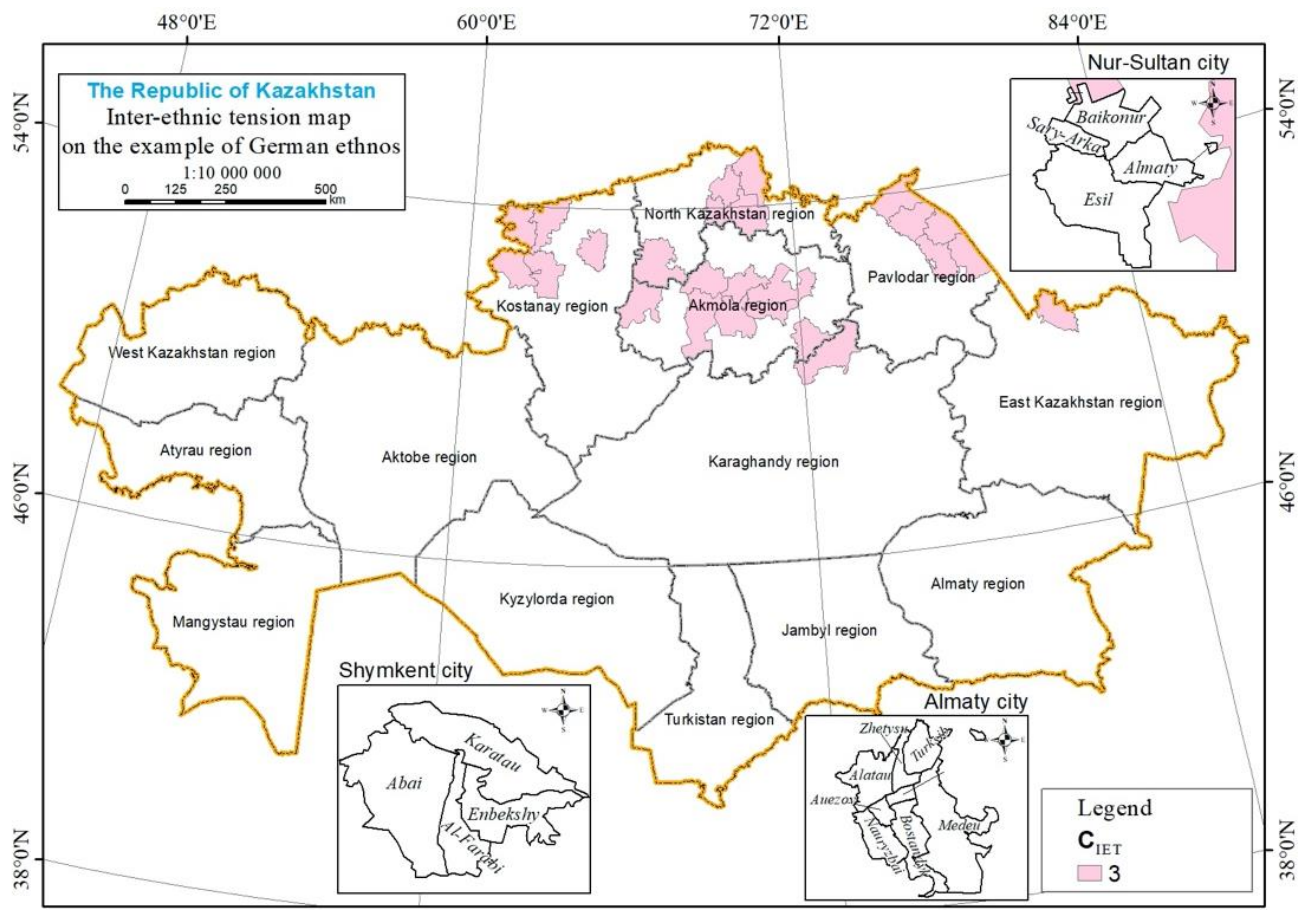

Figure 6. Map of interethnic tension of German Ethnicity (Source: Statistics Committee of the Ministry of National Economy of the Republic of Kazakhstan for 2019 [1])

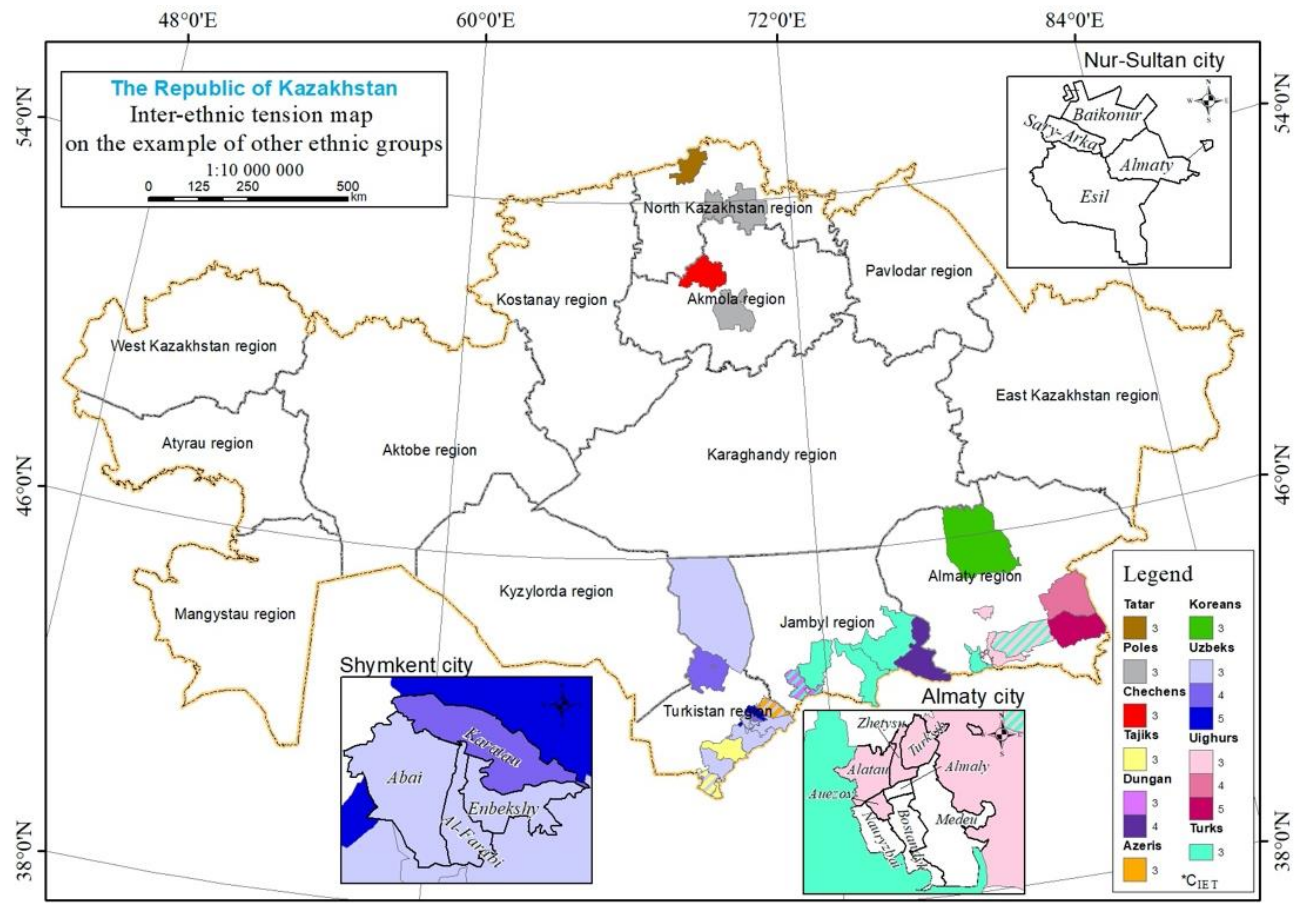

Figure 7. Map of interethnic tension of individual ethnic groups (Source: Statistics Committee of the Ministry of National Economy of the Republic of Kazakhstan for 2019 [1]) 
The northern zone of interethnic tension is also of interest because most ethnic groups (European ethnicities and certain part of other ethnic groups, including Kazakhs, for whom Russian is a first language) comprise the Russian-speaking population, distinguished by Kazakhstan's ethno-political studies as a single major community.

The zones of interethnic tension involving Russian and Uzbek ethnic groups run along the border with Russia and Uzbekistan, the ancestral homelands of these ethnic groups. There are also federation subjects in Russia, which are ancestral homeland for Tatars, Bashkirs and Chechens. The same can be noted for Uighur ethnic group. In the east, Kazakhstan directly borders the Xinjiang Uygur Autonomous Region of China, which is densely populated by Uighurs. However, Uighurs do not have their own state in China. Countries that are ancestral homeland for Ukrainians, Germans, Koreans, Azerbaijanis, Belarusians, Tajiks and Poles do not have direct border with Kazakhstan.

Table 3. Ethnic conflicts in Kazakhstan

\begin{tabular}{|c|c|c|c|c|c|}
\hline Conflict & Location & $\begin{array}{l}\text { Conflicting } \\
\text { ethnic groups }\end{array}$ & Date & & $\begin{array}{l}\text { thnic } \\
\text { s in } \\
\text { gion }\end{array}$ \\
\hline Zhanaozen events & $\begin{array}{c}\text { Zhanaozen, Mangistau } \\
\text { region }\end{array}$ & $\begin{array}{l}\text { Kazakhs vs Lezgins } \\
\text { and Chechens }\end{array}$ & $\begin{array}{c}\text { 17-28 June } \\
1989\end{array}$ & 6 & 1 \\
\hline $\begin{array}{l}\text { Clashes in Ust- } \\
\text { Kamenogorsk }\end{array}$ & $\begin{array}{l}\text { Ust-Kamenogorsk, } \\
\text { East Kazakhstan } \\
\text { region }\end{array}$ & $\begin{array}{l}\text { Kazakhs vs } \\
\text { Chechens }\end{array}$ & $\begin{array}{l}15 \text { October } \\
1992\end{array}$ & 4 & 1 \\
\hline $\begin{array}{l}\text { Anti-Caucasus } \\
\text { protests in Aktau }\end{array}$ & $\begin{array}{l}\text { Aktau, Mangistau } \\
\text { region }\end{array}$ & $\begin{array}{l}\text { Kazakhs vs Lezgins, } \\
\text { Chechens and } \\
\text { Azerbaijanis }\end{array}$ & $\begin{array}{l}20 \text { August } \\
2006\end{array}$ & 5 & 1 \\
\hline $\begin{array}{l}\text { Brawl at the } \\
\text { Tengiz }\end{array}$ & $\begin{array}{c}\text { Zhylyoi district } \\
\text { of Atyrau region, } \\
\text { Tengiz oil field }\end{array}$ & $\begin{array}{l}\text { Kazakhs vs Turks } \\
\text { (Turkish citizens) }\end{array}$ & $\begin{array}{l}\text { October } \\
2006\end{array}$ & 6 & 1 \\
\hline $\begin{array}{l}\text { Kazakh-Uighur } \\
\text { conflict in Shelek }\end{array}$ & $\begin{array}{l}\text { Shelek village, } \\
\text { Almaty region }\end{array}$ & Kazakhs vs Uighurs & $\begin{array}{l}\text { November } \\
2006\end{array}$ & 5 & 3 \\
\hline $\begin{array}{l}\text { Kazakh-Chechen } \\
\text { conflict in Almaty } \\
\text { region }\end{array}$ & $\begin{array}{l}\text { Malovodnoe and } \\
\text { Kazatkom villages, } \\
\text { Enbekshikazakh } \\
\text { district, Almaty region }\end{array}$ & $\begin{array}{l}\text { Kazakhs vs } \\
\text { Chechens }\end{array}$ & \begin{tabular}{|c|} 
17-19 March \\
2007
\end{tabular} & 5 & 2 \\
\hline $\begin{array}{c}\text { Anti-Kurd conflict } \\
\text {-in Mayatas } \\
\text { village }\end{array}$ & $\begin{array}{l}\text { Mayatas village, Tolebi } \\
\text { district of Turkestan } \\
\text { region spreading to } \\
\text { Sairam and Baidibek } \\
\text { districts }\end{array}$ & Kazakhs vs Kurds & $\begin{array}{l}\text { October- } \\
\text { November } \\
2007\end{array}$ & 5 & 2 \\
\hline $\begin{array}{c}\text { Kazakh-Tajik } \\
\text { conflict in } \\
\text { Bostandyk village }\end{array}$ & $\begin{array}{l}\text { Bostandyk village, } \\
\text { Saryagash district of } \\
\text { Turkestan region }\end{array}$ & Kazakhs vs Tajiks & $\begin{array}{l}\text { February } \\
\quad 2015\end{array}$ & 5 & 2 \\
\hline $\begin{array}{c}\text { Ethnic clashes } \\
\text { between Kazakhs } \\
\text { and Turks }\end{array}$ & $\begin{array}{l}\text { Buryl village, Zhambyl } \\
\text { region }\end{array}$ & Kazakhs vs Turks & $\begin{array}{l}\text { February } \\
2016\end{array}$ & 5 & 3 \\
\hline $\begin{array}{l}\text { Fight in the } \\
\text { Ancient Rome } \\
\text { restaurant }\end{array}$ & Karaganda & $\begin{array}{l}\text { Kazakhs vs } \\
\text { Armenians }\end{array}$ & $\begin{array}{c}\text { January } \\
2019\end{array}$ & 4 & $<1$ \\
\hline $\begin{array}{l}\text { Conflict in } \\
\text { Masanchi }\end{array}$ & $\begin{array}{l}\text { Masanchi village, } \\
\text { Kordai district of } \\
\text { Zhambyl region }\end{array}$ & $\begin{array}{l}\text { Kazakhs vs } \\
\text { Dungans }\end{array}$ & $\begin{array}{c}7 \text { February } \\
2020\end{array}$ & 4 & 4 \\
\hline
\end{tabular}


Georgia is ancestral homeland for Meskhetian Turks. Kurds, originally from Kurdistan, do not have their own state. The study found that the Republic of Kazakhstan has areas with significant risk of ethnic conflicts. Moreover, the modern history of Kazakhstan has witnessed such cases in reality (Table 3).

The analysis of table 3 shows that ethnic conflicts in Kazakhstan occur in rural areas, in places populated by particular ethnic minority. Due to its small size, the ethnic minority seeks to consolidate, has its own economic specialization and organizational effectiveness, and therefore enjoys higher income level. The ethnic majority is unconsolidated and has a wide range of specialization. But due to more dispersed settlement, their standard of living seems to be less favorable. This causes a certain level of cumulative frustration. The start of an open conflict can be triggered by a crime committed either by ethnic minority and ethnic majority.

Zhanaozen events, clashes in Ust-Kamenogorsk, anti-Caucasus protests in Aktau, conflict in restaurant Ancient Rome in Karaganda took place in areas where the proportion of ethnic groups opposing the Kazakhs in the total population is so small that $\mathrm{K}_{\mathrm{ET}}<1$. But these cases allow us to conclude that even within settlements with no ethnic neighborhoods and evenly distributed population, there could be public places with temporary or permanent concentration of particular ethnic groups. Within such premises or open spaces, the proportion of ethnic group in the total number of visitors may cause $\mathrm{K}_{\mathrm{ET}}>3$. Such places could potentially be the target of ethnic conflicts.

The case of Tengiz brawl is quite new for Kazakhstan because, for the first time since independence, an ethnic conflict took place between Kazakhs and foreign citizens working in our country who have not historically resided here (Turkish citizens).

A review of the conflicting ethnic groups shows that since Kazakhstan became independent state, there have been no ethnic conflicts between diasporas. All conflicts occurred between Kazakhs and Diasporas. This allows us to argue that the likelihood of conflicts between the dominant and non-dominant ethnic groups is higher than between two non-dominant ethnic groups. However there are Diasporas whose ancestral homeland are in a state of conflict (Armenians - Azerbaijanis, Russians - Ukrainians). It is explained by the fact that in Kazakhstan, Armenians mostly reside in major cities in the northern zone, while Azerbaijanis live in southern rural areas. A significant part of Ukrainians became assimilated with the Russian ethnic group and this fact reduces the interethnic tension. But in Zhambyl, Almaty and Turkestan regions, in cities like Almaty, Taraz and Shymkent, Turkish and Kurdish communities reside closely and densely. This should also be taken into consideration when implementing state ethnic policies.

Since the 1990s, no open conflicts have been recorded between the two largest ethnic groups of the country - Kazakhs and Russians. This is due to the fact that both have lived together for centuries, have relatively identical standard of living and education, certain level of "Soviet inter-ethnic upbringing", reside together across the country without forming densely populated ethnic settlement areas.

Political expert Gulmira Ileuova notes (2016, [2]) that potential conflict between Kazakhs and Russians is typically talked about mainly in terms of a possible confrontation between two countries - Kazakhstan and Russia. In the southern zone of interethnic tension exerted by Kazakh ethnic group (Figure 3), as a result of the efforts by ethnic Kazakh activists, the issues of language, history and identity become politicized, which creates preconditions for growing ethnic discrepancies.

The Republic of Kazakhstan has a paramount task to maintain well-balanced relations between ethnic groups living in the country, which form the population of Kazakhstan, and to gradually reduce the level of interethnic tensions. We explored the reasons and significance of raising interethnic tolerance in the conditions of poly-ethnic 
Kazakhstan, as well as the theoretic and practical bases of a tolerant personality development in the globalizing world (Togaibayeva et al., 2016; Banshchikova et al., 2015; Jackman, 1997; Soldatova, 1998; Yarakhimova, 2001). So the development of cross-border cooperation and various contacts outside the state is observed.

It is important to study of the integration processes and influence of border on its further development especially in such questions as economy, policy, culture and interethnic tension. Timely adaptation to constantly changing external conditions of managing by means of border and cross-border development of regions is necessary (Ogneva, 2015; Cherkovets, 1998; Kindleberger, 1966; Perkmann, 2002). Aiming to achieve homogeneous ethnic composition of the population in order to reduce ET level is fundamentally ineffective. Therefore, the society and the government must implement other appropriate ways to harmonize ethnic relations. One such effective way is tourism. It expands the interaction between different cultures, develops cooperation mechanisms at the international level, serves as a channel for disseminating cultural and educational models focused on openness and mobility, and is considered as an important tool for managing the intercultural dialogue.

Over the years of independence, more than 4 million people have left the Republic of Kazakhstan. Major migration flows include countries like Armenia, Azerbaijan, Belarus, Georgia, Kyrgyzstan, Moldova, Uzbekistan, Russia, Tajikistan, Turkmenistan, Ukraine, USA, Germany, Greece, Israel, Iran, Canada, China, Latvia, Lithuania, Mongolia, Turkey and Estonia. Social networks and the media frequently publish that people who leave the country wish to return and visit the places where they were born and lived. On the other hand, some of them still have relatives in Kazakhstan.

This situation creates conditions for developing sentimental tourism. Some researchers in their studies note that sentimental tourism is characterized by feelings such as nostalgia and homesickness (Kozoviy, 2018). Due to precedents such as Germans, Jews and Russians visiting Kazakhstan for sentimental tourism, travel agencies may add additional specialization, and entertainment sector companies may offer nostalgia products (style, design, repertoire). Depending on ethnic composition of the population, each region can specialize in targeting a particular set of ethnic groups (Li Yang, 2011). However, he writes that tourists prefer authentic cultural activities and overly commercialized performances displease visitors and devalue local traditions.

Therefore, hospitality sector organizations need to include authentic sites for sentimental tourism purposes. Among them holy places. The legacy created by multiple generations of ethnic groups becomes sacred. For example, there is major center of Catholicism situated in the village of Ozernoye in Tayynshi District of North Kazakhstan Region. It was founded in 1936 by Poles deported to Kazakhstan from Volyn. When the residents faced the hunger threat, springs suddenly clogged in the vicinity of the village forming a 5-7 km lake full of fish (Nazarova et al., 2019). This event dates from the Annunciation day - 25 March 1941 - and is considered a miracle. In 1954, the status of special settlers began to ease. And in 1956 the restrictions on residents of Ozernoye were completely lifted. At the same time (in 1955), the miraculous lake dried up, but the channel through which a stream of water passed in 1941 is still visible.

The parish and temple of Matki Bożej Królowej Pokoju were created in the village. In 1998, a cross was put up on the Volyn hill - a monument to all victims of repression in Kazakhstan. Benedictine monks from Switzerland and Carmelite nuns from Czestochowa arrived and live here. On 11 July 2011, the parish in Ozernoye was officially declared the national sanctuary of the Holy Mother the Queen of Peace, the 
patroness of Kazakhstan. The sanctuary is a place of mass pilgrimage for Catholics from all over the country. International meetings of Catholic youth are held here.

Regarding the sentimental tourism, it is worth noting the opinion of Volodymyr Krool, Anatolii Vdovichen, Roman Hyshchuk that many facilities of historical and cultural heritage have great potential, but are not used widely (Krool et al., 2018).

Friendship centers under the Assembly of the People of Kazakhstan and ethniccultural centers can serve as research institutions and resource centers for sentimental tourism (Herman et al., 2019). The friendship centers under the Assembly of the People of Kazakhstan were opened and operate in all regions of the country. The Republican Friendship Center is located in Almaty. In total, there are 12 regional, 7 urban and 13 district friendship centers in the country. Also, there are 321 ethnic-cultural centers. Almost every ethnic group living in Kazakhstan run such centers as public associations.

The development of sentimental tourism can have the following effects on harmonizing ethnic relations:

- full participation of all ethnic communities and groups living in Kazakhstan in all areas of public life;

- facilitating the traditional forms of labor of ethnic communities and groups in the regions (folk arts and crafts);

- forming and spreading the ideas of interethnic and interfaith harmony and cooperation, spiritual unity and patriotism;

- holding workshops, competitions, events and research projects aimed to revive and promote the best traditions and customs of ethnic groups living in the regions of Kazakhstan, using them in educating the young generation, promoting self-awareness based on unifying values and common historical past of all people of Kazakhstan.

Another promising area of tourism development is a cross-border tourism (BarKołelis et al., 2018; Derlaga et al., 2006; Krasnoyarova et al., 2019). It is unique in a sense that it also satisfies the needs of sentimental tourism. Many border areas are already becoming a model of integration of ethnic groups, not only under the influence of economic, social and political factors, but also common cultural and value orientations. This is an important condition for reducing interethnic tension.

For example, in Bosnia and Herzegovina, it was the tourism sector that showed the greatest potential for post-conflict development, but still needs additional research (Causevic et al., 2013, Farmaki, 2016). Kazakhstan has borders with Russia, China, Kyrgyzstan, Uzbekistan and Turkmenistan, which are the ancestral homeland for several ethnic groups living in Kazakhstan In turn, numerous Kazakh Diasporas live in these countries. The participation of bordering countries in cross-border tourism should be of mutual priority, there should not be any significant imbalances in contributing to its development (Krotov et al., 2019). This notion is supported by studies conducted by Zoltán Bujdosó, Lóránt Dávid, Dorottya Varga, Altynbek Zhakupov, Ádám Gyurkó and János Pénzes (Bujdosó et al., 2015).

The forms of cross-border tourism vary from region to region. Sentimental tourism, shopping, scientific (Koshim et al., 2019) and wide range of recreation activities are the priority forms of tourism between Kazakhstan and Russia, Kyrgyzstan, Uzbekistan. The shopping in China is intensively developing. The tourism cooperation with Turkmenistan is poor due to the closed nature of neighboring state. Cross-border tourism is very sensitive to international security (Anyu Liu et al., 2017).

It is already possible to start promoting some areas currently developing in Europe, such as bicycle touring and varieties of eco-tourism (Vujko, 2013; Mazhitova et al., 2018).

In terms of cross-border tourism development, we believe that what needs to be done is to identify key cities and invest in their development. 
These could include Uralsk-Samara, Aktobe-Orenburg, Kostanay-Chelyabinsk, Petropavlovsk-Omsk-Pavlodar, Ust-Kamenogorsk-Barnaul, Almaty-Bishkek, ShymkentTashkent. Cross-border tourism needs the same support of all countries that have common borders, Diasporas and other communities. Such support is especially needed by countries that belong to different political systems (Studzieniecki et al., 2007).

Thanks to the cross-border tourism development, countries will enjoy a multiplier effect both in terms of harmonization of ethnic relations and the economy.

\section{CONCLUSION}

As a result of the study, a statistical analysis of regional contrasts was carried out and it was found that the current interethnic situation in the country can be described as complex and dynamic, varying from region to region. The cartographic method helped to identify two continuous zones of ethnic tension of sub-latitudinal strike and several enclave areas in the Republic of Kazakhstan. Ethnic conflicts took place in areas with $K_{\mathrm{ET}}>3$. They were mostly seen in small rural settlements. Therefore, it is necessary to pay attention to interethnic relations at the micro level to prevent ethnic conflicts more effectively.The major limitation in presenting the results of the study was an informal taboo on the issue of interethnic relations in the Republic of Kazakhstan and the need to observe political correctness. The aim of the study - to determine the spatial boundaries of interethnic tension zones - was a limitation to some extent.

In this regard, the in-depth nature of ethnic conflicts was not considered. Ethnic diversity is not only a factor of tension, but also an opportunity to develop the hospitality sector. Sentimental and cross-border tourism are important tools for harmonizing interethnic relations. The regions of the country have sufficient capacity for its development. It is also appropriate to look at the experience of European countries. The results of the study can be used to assess the state of interethnic relations, correct policies implemented by government agencies and local executive bodies of the Republic of Kazakhstan, as well as to develop special courses in political geography and geopolitics. In this context, promising direction is to determine a "fault zone" in Kazakhstan between the Orthodox and Muslim civilizations.

\section{REFERENCES}

Asaul, A.N., Dzhaman, M.A., Ryibnov, E.I. \& Shukanov, P.V. (2010). Etnogeograficheskie faktoryi globalizatsii i regionalizatsii mira, ANO «IPEV», ISBN 978-5-91460-035-5, SPb.

Banshchikova, T., Solomonov, V. \& Fomina, E. (2015). Attitudes and Tolerance in the Structure of Individual Readiness for Intercultural Interaction. Procedia-Social and Behavioral Sciences, vol. 214, 916-924.

Bar-Kolelis, D. \& Wendt, J.A. (2018). Comparison of cross-border shopping tourism activities at the Polish and Romanian external borders of European Union, Geographia Polonica, vol. 91 (1), 113-125.

Bujdosó, Z., Dávid, L., Varga, D., Zhakupov, A., Dám Gyurkó, Á. \& Pénzes, J. (2015). Tourism development and cross-border cooperation in the Hungarian-Romanian border region. GeoJournal of Tourism and Geosites, vol. 16, 154-164.

Causevica, S. \& Lynchb, P. (2013). Political (in) stability and its influence on tourism development. Tourism Management, vol.34, 145-157.

Cherkovets, O. (1998) Political aspects of regional economic integration, Russian Economic Journal, vol. 1 [in Russian].

Derlaga, A. \& Wendt, J. (2006). Cross-border co-operation between the Republic of Romania, Ukraine and Moldova, w: Kitowski, J. (eds.), Regional transborder co-operation in countries of Central and Eastern Europe - a balance of achievements. Geopolitical Studies, no 14, 141-158, PAN, Warsaw.

Farmaki, A. (2016). The tourism and peace nexus. Tourism Management, vol. 59, 528-540.

Herman, G.V., Wendt, J.A., Dumbravă, R. \& Gozner, M. (2019). The role and importance of promotion centers in creating the image of tourists destination - Romania, Geographia Polonica, 92 (4), 443-454. 
Jackman, M.R. (1977). Prejudice, tolerance, and attitudes toward ethnic groups. Social Science Research, vol. 6 (2), 145-169.

Kindleberger, Ch.P. (1966). European integration and the international corporation. Columbia Journal of World Business, 1(1), 65-76.

Koshim, A.G., Sergeyeva, A.M., Saparov, K.T. \& Wendt, J.A. (2019). Development of scientific tourism at Baikonur Cosmodrome, Kazakhstan. GeoJournal of Tourism and Geosites, 24 (1), 267-197.

Kozoviy, V. (2018). Cultural aspect of sentimental tourism within Ukrainian-Polish Border. GeoJournal of Tourism and Geosites, 23(3), 668-674.

Krasnoyarova, B., Krotov, A. \& Karatabanov, R. (2019). Institutional foundations of cross-border international cooperation, International Conference on Sustainable Development of Cross-Border Regions: Economic, Social and Security Challenges (ICSDCBR 2019), Advances in Social Science, Education and Humanities Research, vol. 364, 275-279, Atlantis Press.

Krool, V., Vdovichen, A. \& Hyshchuk R. (2018). Historical and cultural heritage of the region and its opportunities in tourism and excursion activities (Case of chernivtsi region, Ukraine). GeoJournal of Tourism and Geosites, 23(3), 808-823.

Krotov, A., Karatabanov, R. \& Zan, V. (2019). Problems and prospects of competitiveness of the territories of Greater Altai in the context of sustainable development, International Conference on Sustainable Development of Cross-Border Regions: Economic, Social and Security Challenges (ICSDCBR 2019), Advances in Social Science, Education and Humanities Research, vol. 364, 257-260, Atlantis Press.

Liu, A. \& Pratt, S. (2017). Tourism's vulnerability and resilience to terrorism. Tourism Management, vol. 60, $404-417$.

Mazhitova, G.Z., Pashkov, S.V. \& Wendt J.A. (2018). Assessment of landscape ecological - recreational capacity of north Kazakhstan region.GeoJournal of Tourism and Geosites, 11 (3), 731-737.

Nazarova, T.V., Fomin, I.A., Dmitriyev, P.S., Wendt, J.A. \& Janaleyeva, K.M. (2019). Landscape and limnological research of lake system of the plain areas of the northeastern borderlands of the Republic of Kazakhstan and assessment of their recreational capacity, in GeoJournal of Tourism and Geosites, 25(2), 485-495.

Ogneva, N. (2015). Features of the Organization and Development of Cross-border Cooperation between Regions, in Social and Economic Geography, vol. 1.1, 23-30.

Perkmann, M. (2002). The rise of the Euroregion. A bird's eye perspective on European cross-border cooperation, Department of Sociology, Lancaster University, Lancaster.

Samuel P. Huntington (1996). The Clash of Civilizations And the remaking of World Order, Simon \& Schuster, ISBN o-684-81164-2.

Soldatova, G.U. (1998). Psikhologiya mezhetnicheskoy napryazhennosti [Psychology of ethnic tension], Smysl, Moscow.

Studzieniecki, T. \& Mazurek, T. (2007). How to promote a cross-border region as a tourism destination - the case study of the bug Euroregion, in Tourism Review 62(1), 34-38.

Togaibayeva, A, Yessengulova, M., Zhukenova, G., Ramazanova, D. \& Issembayeva, N. (2016). The Role of Education and Mass Media in the Development of Inter-ethnic Tolerance as a necessary condition for the National Unity of Kazakhstan, in Global Media Journal, S3:21.

Vujko, A. \& Plavša, J. (2013). Possibilities of improving international cross-border cooperation through cycling the "Szekelys route", vol. 12, 185-202.

Yang, Li (2011). Ethnic tourism and cultural representation. Annals of Tourism Research, vol. 38 (2), $561-585$.

Yang, Li \& Wall G. (2009). Authenticity in ethnic tourism: domestic tourists' perspectives. Current Issues in Tourism, vol. 12 (3), 235-254.

Yarakhimova, M.G., (2001) Etnicheskaya tolerantnost i etnicheskie stereotypy podrostkov [Ethnic tolerance], KANON, Moscow.

Zupančič J., Wendt J.A. \& Ilieş A. (2018). An outline of border changes in the area between the Baltic and the Mediterranean: their geopolitical implications and classification, in Geographia Polonica, 91 (1), 33-46.

*** Demograficheskaya statistika. Ekspress-informatsiya \# 36-7/136 ot 12 aprelya 2019 g. Ob utochnennoy chislennosti naseleniya Respubliki Kazahstan na nachalo 2019. Electronic resource: http://stat. gov.kz/official/industry/61/statistic/6 (Date of appeal 26.06.2019).

https://www.ofstrategy.kz/ru/research/socialresearch/item/504-etnicheskij-razlom (retrieved on 09.02.2020).

Submitted:

22.01.2020
Revised:

04.05.2020
Accepted and published online 12.05.2020 